\title{
Insulin-like Growth Factor-I Signaling Mechanisms, Type I Collagen and Alpha Smooth Muscle Actin in Human Fetal Lung Fibroblasts
}

\author{
ANNE CHETTY, GONG-JEE CAO, AND HEBER C. NIELSEN \\ Department of Pediatric Pulmonary [A.C., G.-J.C.] and Newborn Medicine [H.C.N.], Floating Hospital for Children, New England \\ Medical Center; Tufts Medical School, Boston, MA 02111
}

\begin{abstract}
Bronchial wall remodeling is a major morbidity component in oxidant injury in bronchopulmonary dysplasia (BPD) and asthma. Hypothesis: IGF-1 enhances alpha smooth muscle expression and collagen synthesis in developing lung fibroblasts leading to fibrosis through nuclear $\mathrm{NF}_{-} \mathrm{B}$-dependent transcription. We studied $\mathrm{NF}_{-} \mathrm{B}$ dependent transcription by transfecting HFLF with a $\mathrm{NF}_{-} \mathrm{B}$ responsive promoter driving the luciferase gene and treating with IGF-1 (100 ng/mL) and measuring luciferase activity. We exposed cells to the PI-3 kinase inhibitor or the Erk1/2 inhibitor one hr before stimulating with IGF-1. We also used IGF-1 receptor antibody to inhibit the action of IGF-1 and studied its effect on alpha-sma and type I collagen. IGF-1 treatment significantly increased luciferase activity. This was attenuated by PI-3 kinase and MAP-Kinase inhibitors. Western blot analysis showed PI-3 kinase mediates IGF-1 activation of $\mathrm{NF}_{\mathrm{k}} \mathrm{B}$ independent of $\mathrm{I}_{\mathrm{K}} \mathrm{B}$ phosphorylation. We found an up-regulation of phospho NF-kB in the nuclear extract compared with total NFKB showing that IGF-1 regulates $\mathrm{NF}_{-} \mathrm{B}$ transcriptional activity downstream of $\mathrm{NF}_{-\mathrm{k}} \mathrm{B}$ nuclear translocation. IGF-1-induced increase in alpha-sma expression and type-I collagen was significantly inhibited by pretreatment with LY294002 and IGF-1 receptor antibody. IGF-1 cell signaling leading to collagen synthesis in fetal lung fibroblasts is mediated by PI3 Kinase acting through $\mathrm{NF}_{-\mathrm{k}} \mathrm{B}$ in HFLF. (Pediatr Res 60: 389-394, 2006)
\end{abstract}

$I^{\prime}$ n asthma, chronic inflammation leads to pathologic changes in the airways with marked remodeling (1). An increased number of myofibroblasts beneath the bronchial epithelial basement membrane has been described in asthma. Bronchial biopsies of asthmatic patients show thickening of the subepithelial layer due to the deposition of fibrillar collagen (2). The production of mediators by epithelial cells in close proximity to myofibroblasts during epithelial repair after repeated damage is one possible mechanism for airway remodeling (3). IGF-1 and IGF binding proteins (IGFBPs) are active in the pulmonary cellular environment to modulate cell proliferation and function (4). IGF-1 and its receptor, IGF-1R, are also known to modulate repair processes after lung injury (5). Others and we have observed that IGF-1R expression is more intense in areas of increased cell proliferation in developing lung $(6,7)$. These studies prompted us to investigate the hy-

Received March 6, 2006; accepted May 15, 2006.

Correspondence: Anne Chetty, M.D., Department of Box 044, New England Medical Center, 750 Washington Street, Boston, MA 02111; Email: achetty@tufts-nemc org

DOI: 10.1203/01.pdr.0000238257.15502.f4 pothesis that IGF-1 mediated signaling in developing lung cells may induce some of the phenotypic changes that are observed in asthma. We examined the signaling pathway activated by IGF-1 in fetal lung fibroblasts leading to an increase in myofibroblast proliferation and collagen synthesis, and whether this involves nuclear NF-kappaB $\left(\mathrm{NF}_{-\mathrm{k}} \mathrm{B}\right)$-dependent transcription.

\section{MATERIALS AND METHODS}

Reagents were obtained as follows: Recombinant IGF-1 and IGF-1 receptor antibody were purchased from R\&D Systems (Minneapolis, MN). Goat antirabbit IgG was purchased from Upstate Biotechnology (Charlottesville, VA). Penicillin G, acrylamide, DMSO, SDS, pepstatin and leupeptin were purchased from Sigma Chemical Co. (St. Louis, MO). L-glutamine, Hanks balanced salt solution (HBSS), Dulbecco's modified PBS (D-PBS), Dulbecco's minimal essential medium (DMEM) and FCS were obtained from GIBCO (Grand Island, NY). The PI-3 kinase inhibitor LY 294002, ERK-1/2 inhibitor PD 98059, and antibodies against phospho-AKT, AKT, phospho-ERK and ERK were purchased from Cell Signaling (New England Biolabs, Ipswich, MA).

Cell culture. The cell line chosen in this study is a human fetal lung fibroblast cell line (HFLF), which was derived from fetal lung fibroblasts. We have used this cell line successfully to model pulmonary cell-cell interactions in co-cultures with pulmonary epithelial cells in a three-dimensional collagen gel (8). HFLF from American Type Culture Collection (Rockville, MD) were cultured in DMEM containing $10 \% \mathrm{FCS}$, penicillin $\mathrm{G}(100 \mathrm{U} / \mathrm{mL})$, streptomycin $(100 \mu \mathrm{g} /$ $\mathrm{mL})$, amphotericin $(2 \mu \mathrm{g} / \mathrm{mL})$ and L-glutamine $(500 \mu \mathrm{M})$ at $37^{\circ} \mathrm{C}$ in $5 \% \mathrm{CO}_{2} /$ $95 \%$ air. Cells were plated at a density of $2 \times 10^{5}$ per well in six well plates. Sub-confluent cultures were serum-starved for $24 \mathrm{~h}$ followed by treatment with DMEM containing IGF-1 with and without the inhibitors. The concentration of IGF-1 used (100 ng/mL) was determined in experiments described below and this dose has also been used by others in fibroblasts and other cells $(9,10)$. To see if IGF-1 receptor (IGF-1R) has any effect on IGF-1 stimulated responses we used $5 \mu \mathrm{g} / \mathrm{mL}$ of IGF-1R antibody (A12) kindly provided by Imclone systems, NY.

Cell proliferation assays. Assays were performed in quadruplicate using a calorimetric method for determining the number of viable cells in proliferation. MTS, a tetrazolium compound was bio-reduced into a colored formazon product by living cells in proliferation. Serum-starved cells plated in 96 well plates were pretreated with PI-3 kinase inhibitor, LY $294002(50 \mu \mathrm{M} / \mathrm{mL})$, MAP kinase inhibitor PD $98059(5 \mu \mathrm{M} / \mathrm{mL})$, or IGF-1 receptor antibody $(5 \mu \mathrm{g} / \mathrm{mL})$ before treatment with IGF-1 $(100 \mathrm{ng} / \mathrm{mL})$. The concentration of IGF-1 was determined by prior dose response experiments. At the completion of the experiment, cells were incubated with MTS (ONE Solution Reagent, Promega) for two hours and the absorbance was recorded at $490 \mathrm{~nm}$ in a 96 well plate reader.

PI-3 kinase and MAP-kinase activities. Cells were plated in six well plates at a density of $2 \times 10^{5}$ cells per well. $95 \%$ confluent cells were serum-starved with 0.5\% BSA for four hours, exposed to either the PI-3 kinase inhibitor (LY 294002) or the Erk1/2 inhibitor (PD 98059) at $50 \mu \mathrm{M}$ concentration. After one-hour incubation with the inhibitor, IGF-1 (100 ng/mL) was added and cultures continued for $12 \mathrm{~h}$. The proteins were separated from cell lysates by PAGE and the

Abbreviations: $\boldsymbol{\alpha}$-sma, alpha smooth muscle actin; BPD, bronchopulmonary dysplasia; ERK, extracellular signal regulated kinase; IGFBP-3, IGF binding protein-3; MAP, mitogen activated protein kinase; PI-3 kinase, phosphatidylinositol 3-kinase 
activation of PI-3 kinase and MAP kinase evaluated by Western blot analysis. The duration of exposure to IGF-1 was determined by preliminary time series experiments. The doses used for LY294002 and PD98059 have been found to be physiologic and used by others in fibroblast cell cultures to block PI-3 kinase and MAP Kinase pathways (11) (12).

Western blot analysis. A 50- $\mu$ g protein sample was separated by PAGE on a $10 \%$ acrylamide-SDS gel then transferred to a nitrocellulose membrane. The membranes were probed using antibodies to phospho-AKT, AKT, phospho- $\mathrm{I}_{\mathrm{K}} \mathrm{B}$, $\mathrm{I}_{\mathrm{K}} \mathrm{B}$ and phospho-ERK and ERK (Cell Signaling) at 1:1000 dilution. The membranes were incubated in the presence of primary antibody at $4^{\circ} \mathrm{C}$ overnight. Following a sequence of washes in TBST, the membranes were incubated with goat anti-rabbit $\operatorname{IgG}(1: 30,000$ in TBST) for one hour at room temperature. Antigens were identified using chemiluminescence (Amersham, Life Science, Bio-Rad) and exposure to X-ray film. Comparisons of relative changes were made by densitometry scanning. Actin was used as an internal standard. The membranes were also probed with Type-I anti-collagen antibody, and with mouse monoclonal anti-human $\alpha$-sma antibody (R\&D Systems).

Transient transfection and luciferase assay. Cells were transiently transfected with a DNA plasmid construct expressing the luciferase gene under the control of $\mathrm{NF}_{-\mathrm{k}} \mathrm{B}$ DNA binding site. pTK81- $\mathrm{NF}_{-\mathrm{k}} \mathrm{B}$-Luc containing two copies of the annealed oligonucleotide sequence 5'- CGCGGGGACTTTCCC gtac GGGGACTTTCCCG-CGgtac-3' in the antisense orientation $5^{\prime}$ to the luciferase gene in the KpnI site in the vector pTK81-Luc was kindly provided by William L Lowe Jr, M D (Northwestern University Medical School). Since renilla based reporters are frequently used as transfection controls for luciferase transcriptional reporter assays, we used this system as an internal standard. For transfection assays, the fibroblasts were plated onto 12-well plates at a density of $1 \times 10^{5}$ cells per well. Plasmid DNA was transfected into cells using the cationic lipid Lipofectin (Life Technologies, Inc, Gaithersburg, M.D.), according to the manufacturer's instruction. Cells were incubated overnight in Opti-mem (Promega, Madison, WI) with Lipofectin and plasmid DNA.

Luciferase assay. Transfected cells were transferred to serum-free DMEM $+0.25 \%$ BSA for four hours. The inhibitors to PI-3 kinase and MAP kinase were added at $50 \mu \mathrm{M}$ concentration one hour before treating with IGF-1 (100 $\mathrm{ng} / \mathrm{mL}$ ) overnight. The cells were harvested, and luciferase activity measured by luminometer (Monolight, BD Biosciences) as described (13), and normalized to renilla luciferase. All assays were performed in triplicate.

Western blot analysis of $\mathrm{P65}$ subunit of phospho $\mathrm{NF}_{-} \mathrm{B}$ analysis in nuclear extracts. Cells were serum-starved overnight before treatment with inhibitors and the growth factor as described above. Nuclear extracts were prepared using the Celytic ${ }^{\mathrm{TM}}$ NuClear Extraction kit (Sigma Chemical Co.) and stored at $-70^{\circ}$ until further analysis. The nuclear extract was separated by PAGE, and the membrane was probed with antibody directed against phospho $\mathrm{NF}_{-} \mathrm{B}$ and total $\mathrm{NF}_{-} \mathrm{B}$ p65 subunit of $\mathrm{NF}_{-} \mathrm{B}$ (1:1000 dilution) (Cell Signaling). The Phospho $\mathrm{NF}_{\mathrm{k}} \mathrm{B}$ p65 (Ser536) antibody detects $\mathrm{NF}_{-} \mathrm{B}$ p65 only when phosphorylated at serine 536 .

Immunohistochemistry of alpha smooth muscle actin expression analysis. Fixed, permeabilized cells were blocked with PBS containing 0.1\% Triton X-100, $1 \%$ BSA, and $10 \%$ normal donkey serum at room temperature for $45 \mathrm{~min}$. Cells were incubated with a mouse anti- $\alpha$-sma MAb (1:1000) overnight at $4^{\circ} \mathrm{C}$ followed by Rhodamine Red-coupled anti-mouse $\operatorname{lgG}$ at RT in the dark for one hour. Images were acquired on a Zeiss Axiovert microscope equipped with a Sutter DG-4 Xenon fluorescence excitation source, Hamamatsu cooled-CCD digital camera, and a PC running Metamorph 5.0 (Universal Imaging Systems) at the GRASP Center/Tufts Center for Neuroscience Research Imaging Facility. Color was added in Metamorph after image acquisition. $\alpha$-sma expressing cells from four independent experiments were scored from a total of 20 cells in each of three different fields and the percentage of $\alpha$-sma-expressing cells was determined using Scion imaging software to quantitate fluorescence.

Data analysis. Densitometry was used for quantitative analysis for Western blots. Data are represented as mean \pm SEM. Statistical analysis to determine the effect of IGF-1 with and without the inhibitors was performed using one-way analysis of variance with Bonferroni correction for multiple comparisons. Differences between control and treated cells were considered statistically significant if $p$ values were $<0.05$.

\section{RESULTS}

Effect of IGF-1 on the PI-3 kinase-signaling pathway in human fetal lung fibroblasts. Since we have shown in our earlier studies $(14,15)$ that IGF-1 plays an important role in oxidant injury in developing lung, we chose to investigate the signaling pathway of IGF-1 in human fetal lung fibroblasts. Western blots were used to evaluate the phosphorylated form of AKT and total AKT, known also as protein kinase ${ }_{\mathrm{B}}$ (Fig. 1A).
A

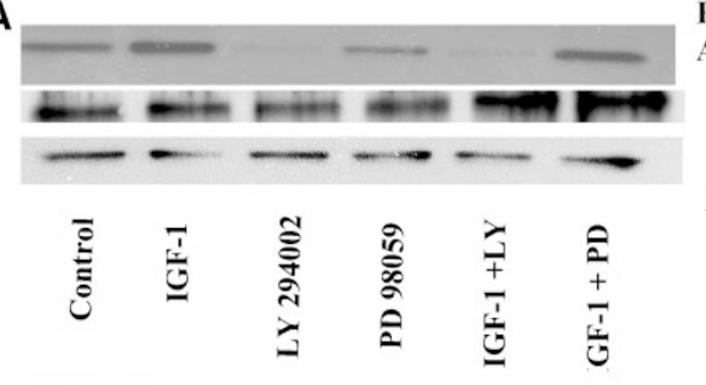

Phospho-

AKT

AKT

Actin

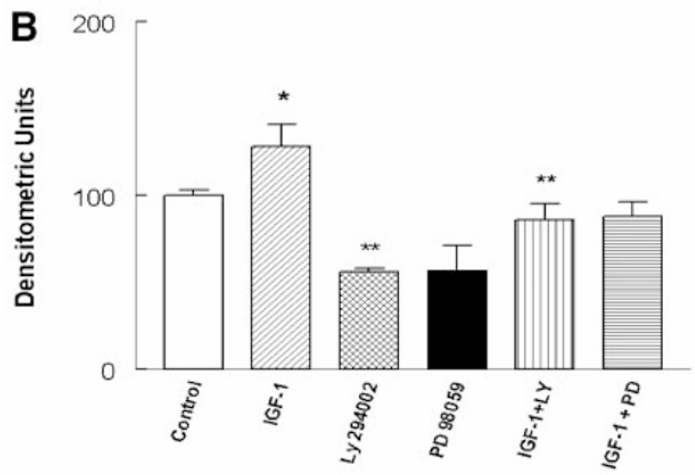

Figure 1. Effect of IGF-1 on PI 3 kinase pathway in human fetal lung fibroblasts. Western blots were probed for phospho Akt and re-probed with AKT antibody. (A) Representative Western blot for phospho AKT and AKT. $(B)$ The histogram shows results of quantitative densitometry of protein levels of the ratio of Phospho AKT to AKT in the cells. Bars represent the mean \pm SEM of $n=3$ experiments. * $p<0.05$ compared with control cells; ** $p<$ 0.05 compared with cells treated with IGF-1 $(100 \mathrm{ng} / \mathrm{mL})$.

IGF-1 treatment significantly increased Phospho AKT, suggesting that IGF-1 signaled through the PI-3 kinase pathway. This was confirmed by the ability of LY 294002 to block AKT phosphorylation with IGF-1 treatment (Fig. 1B). The ability of IGF-1 to increase AKT phosphorylation was not changed in the presence of the MAP-kinase inhibitor PD 98059 (Fig. 1A) showing that there is no cross talk between these two pathways.

Effect of IGF-1 on ERK phosphorylation in HFLF. Next we examined the effects of IGF-1 on ERK1/2 members of the MAP-Kinase signaling pathway. There was no significant increase in ERK 1/2 phosphorylation with IGF-1 $(100 \mathrm{ng} / \mathrm{mL})$, nor did either PD 98059 or LY 294002 alter ERK 1/2 phosphorylation in the presence of IGF-1 (Fig. 2A,B).

Effect of IGF-1 on $\mathrm{NF}_{\boldsymbol{k}_{k}} \mathrm{~B}$ transcriptional activity in HFLF. Having shown that IGF-1 activates the PI-3 kinase pathway we investigated the ability of IGF-1 to increase $\mathrm{NF}_{-\mathrm{k}} \mathrm{B}$ transcriptional activity. We transfected HFLF using pTK81- $\mathrm{NF}_{\mathrm{k}} \mathrm{B}-\mathrm{Luc}$, a fusion gene as described in Methods. IGF-1- increased luciferase activity was significantly inhibited by PI-3 kinase and by MAPkinase inhibitors at $50 \mu \mathrm{M}$ (Fig. 3) suggesting that these pathways contribute to IGF-1-induced activation of $\mathrm{NF}_{-} \mathrm{B}$.

Since we found an increase in $\mathrm{NF}_{\mathrm{k}} \mathrm{B}$ activity in IGF-1 treated cells we further investigated the mechanism of IGF1-induced $\mathrm{NF}_{-\mathrm{k}} \mathrm{B}$ activation. An important event in the activation of $\mathrm{NF}_{\mathrm{k}} \mathrm{B}$ is its release from the inhibitory protein $\mathrm{I}_{\mathrm{K}} \mathrm{B}$ followed by translocation into the nucleus. To evaluate the release for nuclear translocation of $\mathrm{NF}_{\mathrm{k}} \mathrm{B}$, we studied $\mathrm{I}_{\mathrm{K}} \mathrm{B}$ phosphorylation and degradation. Surprisingly we did not find any change in $\mathrm{I}_{\mathrm{K}} \mathrm{B}$ phosphorylation or degradation with IGF-1 
A
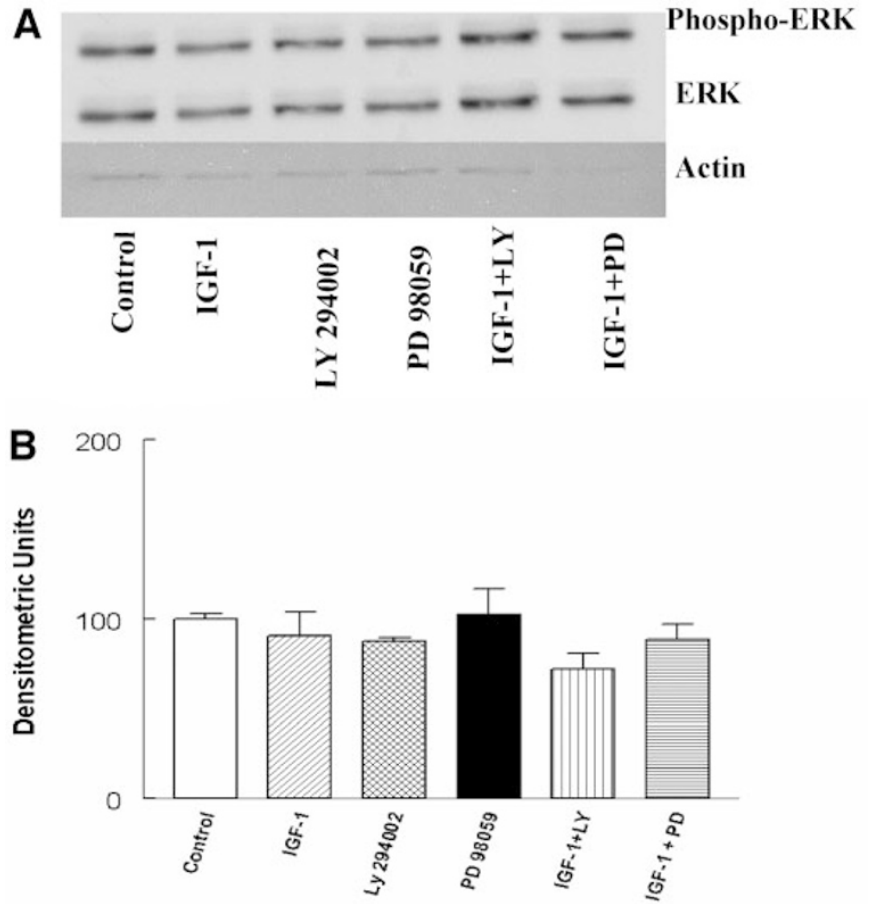

Figure 2. Effect of IGF-1 on ERK phosphorylation in human fetal lung fibroblasts. Western blots were probed with the antibody for phospho-ERK$1 / 2$ and re-probed with antibody for total ERK1/2. (A) Representative Western blot for phospho ERK and ERK. (B) The histogram shows results of quantitative densitometry of protein levels of Phospho ERK and ERK in the cells. Bars represent the mean \pm SEM of $n=3$ experiments. 1: Control; 2: IGF-1; 3: LY294002; 4: PD 98059; 5: IGF-1+Ly; 6: IGF-1+PD.

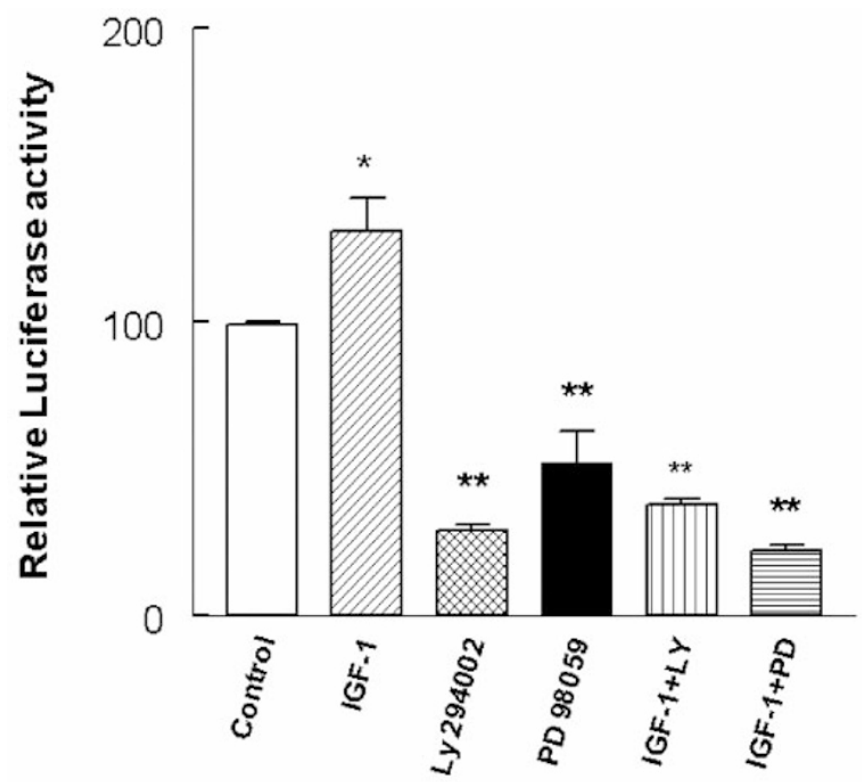

Figure 3. Effect of IGF-1 on $\mathrm{NF}_{\mathrm{K}} \mathrm{B}$ activity in human fetal lung fibroblasts. The histogram shows quantitative representations of Luciferase activity. The values represent relative luciferase activity compared with control. Bars represent the mean \pm SEM of $n=3$ experiments. $* p<0.05$ compared with control cells; **p $<0.05$ compared with cells treated with IGF-1.

(Fig. 4). A similar stimulation of $\mathrm{NF}_{-\mathrm{k}} \mathrm{B}$-derived gene transcription without increased Ik -B phosphorylation has been previously reported in bovine pulmonary artery endothelial cells (16).

To investigate the nuclear translocation of $\mathrm{NF}_{\mathrm{k}} \mathrm{B}$, nuclear extracts were prepared from fetal lung fibroblasts stimulated with IGF-1 (100 ng/mL) overnight after pretreatment for $1 \mathrm{~h}$ with PI-3 kinase or MAP kinase inhibitors as described above. The nuclear extracts were separated by PAGE, transferred to membranes, and the membranes probed with antibody directed against the p65 subunit of phospho $\mathrm{NF}_{-\mathrm{k}} \mathrm{B}$ and total $\mathrm{NF}_{-} \mathrm{B}$. Phospho-NF- ${ }_{k} \mathrm{~B}$ p65 (Ser536) antibody detects $\mathrm{NF}_{-\mathrm{k}} \mathrm{B}$ p65 only when phosphorylated at serine 536. The antibody does not cross-react with the p50 subunit or other related proteins (17). $\mathrm{NF}_{-\mathrm{k}} \mathrm{B}$ p65 antibody detects endogenous levels of total $\mathrm{NF}_{-\mathrm{k}} \mathrm{B}$. We found that IGF-1-induced increase in nuclear phospho $\mathrm{NF}_{-\mathrm{k}} \mathrm{B}$ was inhibited both by the PI-3 kinase and the MAP kinase inhibitors at $50 \mu \mathrm{M}$ concentrations, and by IGF-1 receptor antibody at $5 \mu \mathrm{g} / \mathrm{mL}$ (Fig. $5 \mathrm{a}$ and b). These data suggest that IGF-1 regulates $\mathrm{NF}_{-\mathrm{k}} \mathrm{B}$ nuclear transcriptional activity independent of changes in $\mathrm{I}_{\mathrm{K}} \mathrm{B}$ phosphorylation.

IGF-1 stimulation of collagen synthesis in HFLF. Based on our previous studies showing that hyperoxia increased collagen synthesis in neonatal rat lung explant cultures, and also increased IGF-1 in epithelial cells $(7,18)$, we investigated the effect of IGF-1 on Type I collagen in fetal lung fibroblasts with and without PI-3 kinase and MAP-kinase inhibitors. Figure 6 shows a representative Western blot for Type I collagen and $\beta$-Actin and the summary of densitometry analysis. There was a significant increase in collagen in cells treated with IGF-1 compared with controls, which was significantly inhibited in the presence of LY 294002. These data

A
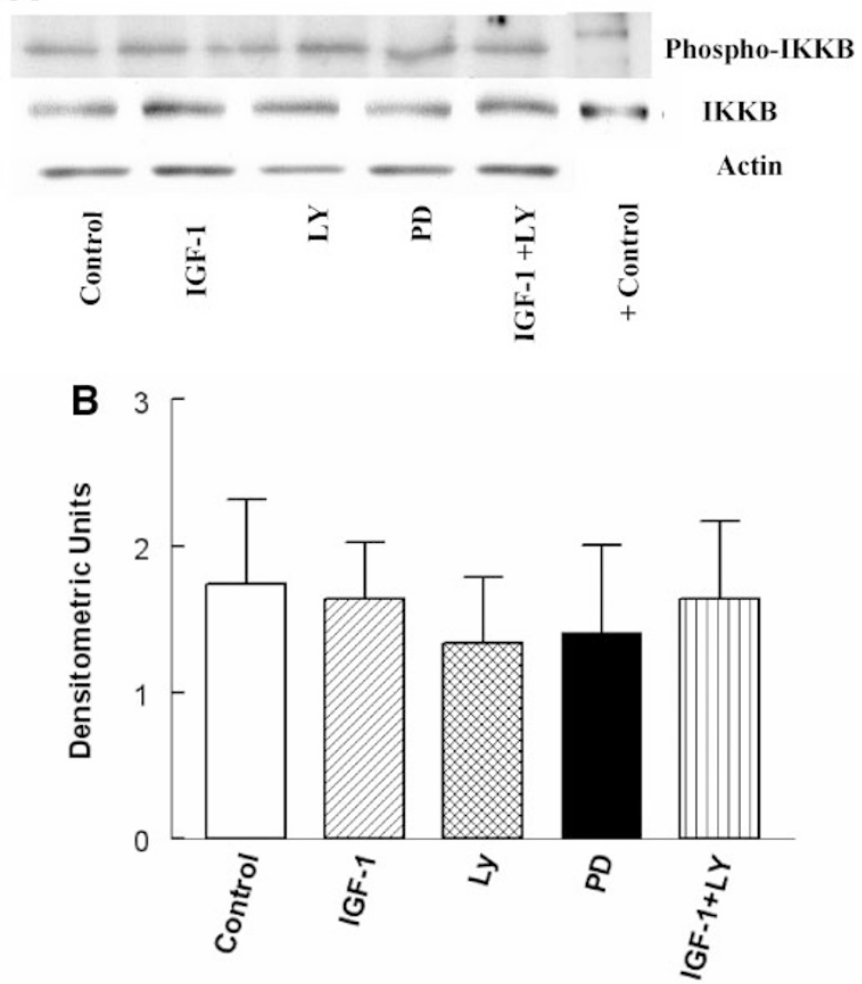

Figure 4. Effect of IGF-1 on $\mathrm{I}_{\mathrm{K}} \mathrm{B}$ phosphorylation in human fetal lung fibroblasts. Cell lysates were prepared and Western blots were probed for phospho$\mathrm{I}_{\mathrm{K}} \mathrm{B}$ and re-probed with $\mathrm{I}_{\mathrm{K}} \mathrm{B}$ antibody. (A) Representative Western blot for phospho $\mathrm{I}_{\mathrm{K}} \mathrm{B}$ and $\mathrm{I}_{\mathrm{K}} \mathrm{B}$. Jurkat whole cell lysate (Santa Cruz Biotechnology) was used as positive control for $\mathrm{I}_{\mathrm{K}} \mathrm{B}$ (Fig. $4 A, B$ ). (B) Densitometry of protein levels of phospho $\mathrm{I}_{\mathrm{K}} \mathrm{B} /$ Actin. Bars represent the mean \pm SEM of $n=3$ experiments. 

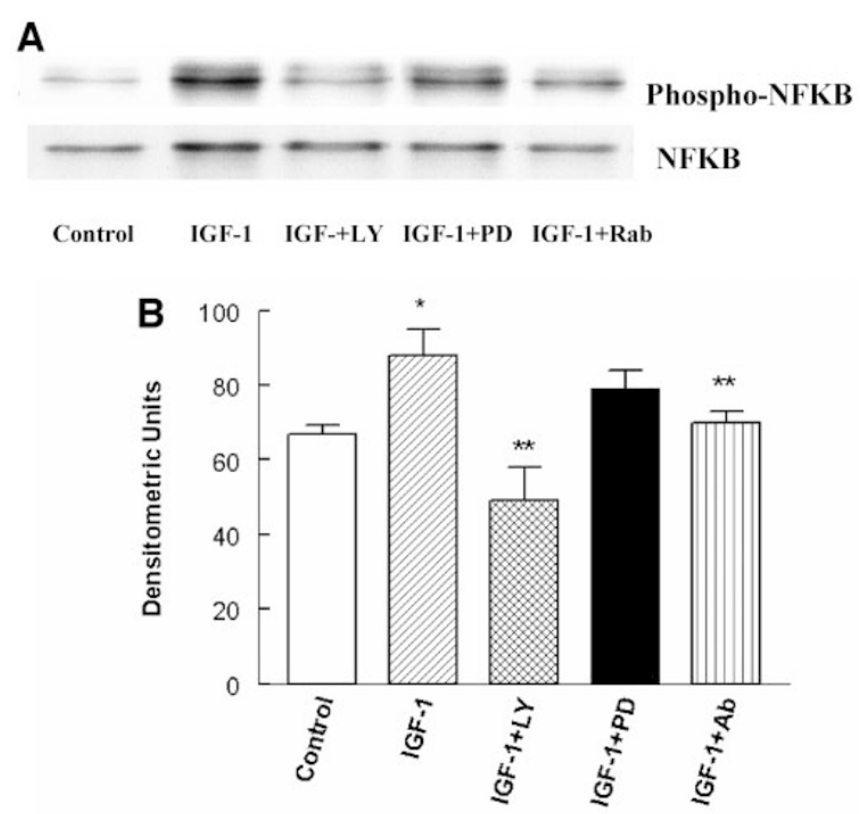

Figure 5. $\mathrm{NF}_{\mathrm{k}} \mathrm{B}$ (P65 subunit) analysis in nuclear extracts from HFLF. The nuclear extract was separated by PAGE and the membranes were probed with antibody directed against the p65 subunit of $\mathrm{NF}_{-} \mathrm{B}$ and phospho $\mathrm{NF}_{-\mathrm{k}} \mathrm{B}$ (Ser536). (A) Representative blot of phospho $\mathrm{NF}_{-\mathrm{k}} \mathrm{B}$ and $\mathrm{NF}_{-\mathrm{k}} \mathrm{B}$ p65 (B) The histogram shows quantitative representations of protein levels of Ser536 Phospho $\mathrm{NF}_{-} \mathrm{B}$ (P65 subunit) in the nuclear extracts of the cells (Bars represent mean \pm SEM of $n=3$ experiments). ${ }^{*} p<0.05$ compared with control cells; $* * p<0.05$ compared with cells treated with IGF-1 $100 \mathrm{ng} / \mathrm{mL}$. Rab, receptor antibody.
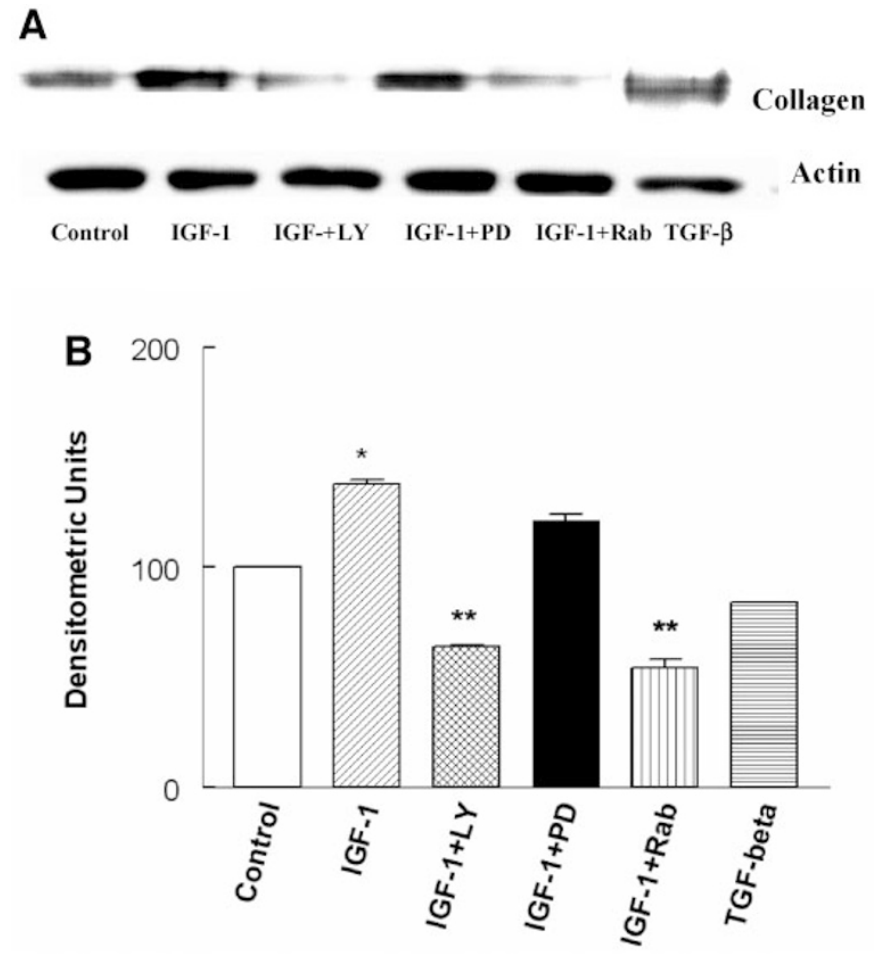

Figure 6. Effect of PI3 kinase inhibitors on IGF-1 stimulated collagen synthesis in HFLF. Western blots were probed for Type I collagen and re-probed for actin antibody. (A) Representative Western blot for Type I collagen and Actin. $(B)$ The histogram shows quantitative densitometry of protein levels of Type I collagen/actin ratio in the cells. Bars represent the mean \pm SEM of $n=3$ experiments. * $p<0.05$ compared with untreated cells; $*^{*} p<0.05$ compared with cells treated with IGF-1. Rab, receptor antibody. show that PI-3 kinase plays an important role in IGF-1 stimulated type I collagen production in fetal lung fibroblasts.

$P I-3$ kinase inhibition and IGF-1 receptor antibody block IGF-1 stimulated increases in $\alpha$-sma and cell proliferation. Previous studies have documented a stimulatory effect of IGF-1 on myofibroblast proliferation at sites of inflammation $(19,20)$, although the signal transduction pathways for increased $\alpha$-sma in fetal lung fibroblasts have not been identified. We found that IGF-1 stimulated a 2-fold increase in $\alpha$-sma protein. There was a robust inhibition of IGF-1stimulated increase in $\alpha$-sma by Ly 294002 , and by IGF- 1 receptor antibody (Fig. $7 A, B)$ ). We also observed a moderate inhibition of IGF-1-stimulated increase in $\alpha$-sma by PD 98059 . Immunohistochemistry confirmed these changes in $\alpha$-sma (Fig. 8A,B). In addition, the IGF-1 - induced increase in cell proliferation was significantly inhibited by IGF-1 receptor antibody and PI-3 kinase and MAP kinase inhibitors (Fig. 9A).

\section{DISCUSSION}

The main aim of the present study was to evaluate the mechanisms by which IGF-1 alters type-I collagen and $\alpha$-sma expression in HFLF, since these cells are involved in airway remodeling in neonatal hyperoxic lung injury leading to CLD, airway hyper-reactivity, and increased incidence of subsequent asthma. In our earlier studies we have shown that IGF-1 is up-regulated in type II epithelial cells after hyperoxic exposure of neonatal rat lung explant cultures (8) (7). In addition, profibrotic cytokines are increased in bronchoalveolar fluid of preterm infants who developed chronic lung disease (21). IGF-1 and other profibrotic cytokines lead to airway remodeling with increased thickness of interstitial matrix (22)

\section{A}
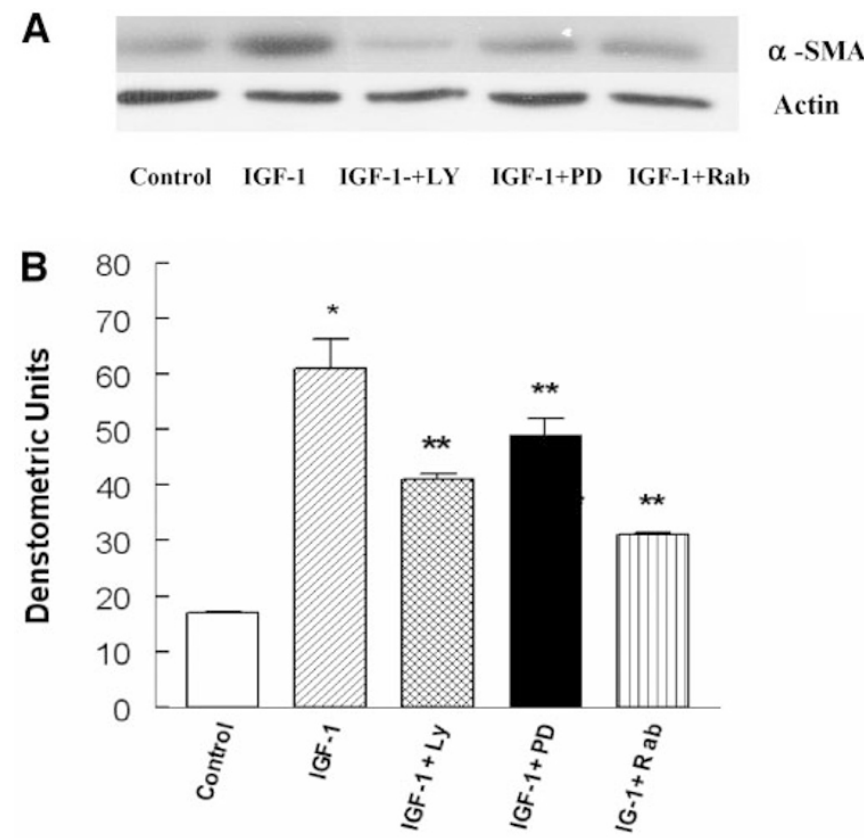

Figure 7. Effect of PI 3 kinase inhibitors on IGF-1 stimulated $\alpha$-sma in HFLF. Western blots were probed for $\alpha$-sma antibody and re-probed for actin $(A)$ Representative Western blot for $\alpha$-sma and actin. (B) Densitometry of the $\alpha$-sma/actin protein ratio Bars represent the mean \pm SEM of $n=3$ experiments. $* p<0.05$ compared with control cells; $* * p<0.05$ compared with cells treated with IGF-1. 
(23). The airway hyper-responsiveness is primarily a function of contraction of airway smooth muscles (24).

In this study we sought to identify the point(s) in the IGF-1 signal transduction pathways, which are activated to increase the population of $\alpha$-sma-positive cells in the airways. We found out that IGF-1 stimulated AKT phosphorylation which was inhibited by pre-treatment with LY294002, strongly suggesting that PI-3 kinase is activated by IGF-1. PI-3 kinase activation due to IGF-1 has been shown in other systems, including bovine pulmonary vascular endothelial cells (25). We also showed that activation of the ERK-1 and ERK-2 members of MAPK family in response to IGF-1 was not significant in these cells, suggesting that PI-3 kinase activation is the major pathway involved in IGF-1 mediated increase in $\alpha$-sma expressing cells. The doses used for LY294002 and PD98059 used in this study act against physiologic levels of IGF-1 and were used by others in fibroblast cell cultures to block PI-3 kinase and MAP Kinase pathways $(26,27)$.

Having shown the effect of IGF-1 on the PI-3 kinase pathway, we next examined the downstream mechanisms activated by this pathway. One mechanism of IGF-1 mediated effects is $\mathrm{NF}_{-} \mathrm{B}$ dependent transcriptional activation. At baseline $\mathrm{NF}_{-} \mathrm{B}$ is generally present as a dimer with the inhibitory $\mathrm{I}_{\mathrm{k}} \mathrm{B}$ protein. Upon activation, $\mathrm{I}_{\mathrm{k}} \mathrm{B}$ is phosphorylated allowing $\mathrm{NF}_{-\mathrm{k}} \mathrm{B}$, to disassociate and translocate to the nucleus to exert its transcriptional regulation properties. Previous studies demonstrated IGF-1 stimulates $\mathrm{NF}_{\mathrm{k}} \mathrm{B}$ dependent gene transcription in neuronal (13) and endothelial cells (8). In this study we showed that IGF-1 increases $\mathrm{NF}_{-\mathrm{k}} \mathrm{B}$ dependent transcription in human fetal lung fibroblasts using a construct containing a $\mathrm{NF}_{-\mathrm{k}} \mathrm{B}$ responsive promoter driving the luciferase gene. The stimulation of $\mathrm{NF}_{\mathrm{K}} \mathrm{B}$ dependent transcription was attenuated both by the PI-3 kinase inhibitor LY 294002, and by the MAPK1 inhibitor PD98059 suggesting that both these pathways have a role in IGF-1-induced activation of $\mathrm{NF}_{-\mathrm{k}} \mathrm{B}$. This is in agreement with the effect of IGF-1 seen in neuronal cells (28).

We further investigated the mechanism of IGF-1-induced $\mathrm{NF}_{\mathrm{k}} \mathrm{B}$ activity. NF- $\kappa \mathrm{B}$, a heterodimer composed of $\mathrm{p} 50$ and $\mathrm{p} 65$ subunits, is a potent activator of gene expression from NF- $\kappa \mathrm{B}$ DNA biding sites due to the presence of transactivating domains located in the C-terminal region of the p65 protein (29). Regulation of gene expression by $\mathrm{NF}_{-} \mathrm{B}$ is controlled through signaling mechanisms that promote nuclear translocation after $\mathrm{I}_{k} \mathrm{~B}$ degradation and through mechanisms that are responsible for up-regulating the transactivation function of $\mathrm{NF}_{-\mathrm{k}} \mathrm{B}$. Surprisingly, we did not find any increase in either nuclear p65 levels or the phosphorylation or degradation of $\mathrm{I}_{\mathrm{k}} \mathrm{B}$. These data suggest that IGF-1 regulates $\mathrm{NF}_{-} \mathrm{B}$ transcriptional activity downstream of $\mathrm{NF}_{-\mathrm{k}} \mathrm{B}$ nuclear translocation. This is in agreement with a recent study that showed that both PI-3 kinase and AKT were able to stimulate the transcriptional activity of $\mathrm{NF}_{-\mathrm{k}} \mathrm{B}$ by inducing changes in basal activity of nuclear $\mathrm{NF}_{\mathrm{k}} \mathrm{B}$ rather than influencing nuclear translocation (30). We found an up-regulation of phospho $\mathrm{NF}_{-\mathrm{k}} \mathrm{B}$ in the nuclear extract compared with total $\mathrm{NF}_{-} \mathrm{B}$ suggesting that activated PI-3 kinase or AKT stimulates $\mathrm{NF}_{-} \mathrm{B}$ dependent transcription by stimulating the phosphorylation of the nuclear p65 subunit of $\mathrm{NF}_{-k} \mathrm{~B}$ rather than by inducing $\mathrm{NF}_{-\mathrm{k}} \mathrm{B}$ nuclear translocation via $\mathrm{I}_{\mathrm{k}} \mathrm{B}$ degradation.

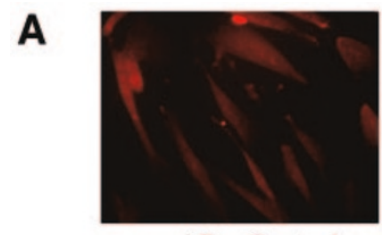

AB - Control

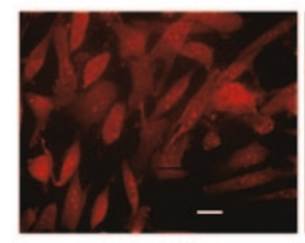

IGF-1

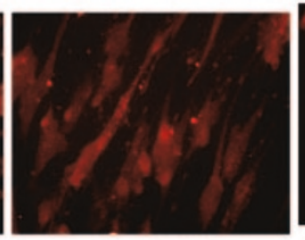

LY 280059

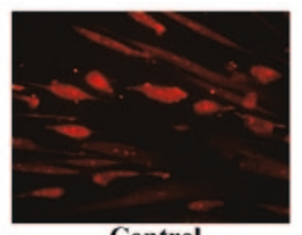

Control

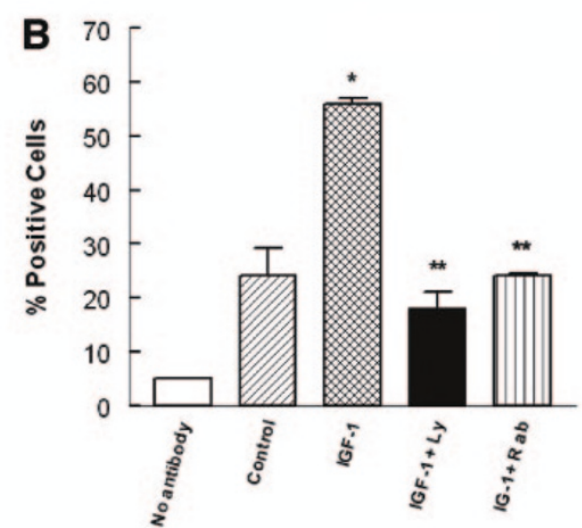

Figure 8. (A) Representative immunofluorescence for $\alpha$-sma in control cells and in cells treated with IGF-1, IGF-1+ PI-3 kinase inhibitor (LY 294002), and IGF-1 + IGF-1R antibody. A negative control (no primary antibody) is also shown (bar, $40 \mu \mathrm{M}$ ). (B) Histogram shows the percent of $\alpha$-sma positive cells in fetal lung fibroblasts stimulated with IGF-1 with and without PI-3 kinase inhibitor or IGF-1R antibody, $n=3$ experiments. ${ }^{*} p<0.05$ compared with untreated cells; $*^{*} p<0.05$ compared with cells treated with IGF-1.

Cellular responses to oxidative stress are regulated by the type 1 IGF-1 receptor $(31,32)$. Oxidant injury implicated in the pathophysiology of bronchopulmonary dysplasia acutely up-regulates IGF-1R expression in the lung. This led us to suspect that IGF-1 receptor blockade in lung tissue could prevent the deleterious effects of hyperoxia. It has been shown that IGF-1 receptor antibody fully blocked the IGF-1 mediated inhibition of apoptosis and increase in cell proliferation (33) (34). Our results show that antibody blockade of IGF-1 receptor inhibited IGF-1 stimulation of $\alpha$-sma expression in fetal lung fibroblasts both by Western blot analysis and by immunohistochemistry, and inhibited stimulation of cell proliferation. The inhibition of IGF-1-induced cell proliferation with these inhibitors has also been shown in other cell lines including human ES cells. Proliferation in these cells is mediated primarily via the PI 3-kinase/Akt signaling pathway, using the IGF-1 receptor as an upstream activator (35).

Increase in $\alpha$-sma expression in lung injury is often associated with an increase in collagen synthesis. Therefore we studied collagen production in neonatal lung by analyzing the content of type I collagen. As part of the repair process following lung inflammation, fibroblasts proliferate and produce large amounts of collagen. It has been shown that IGF-1 


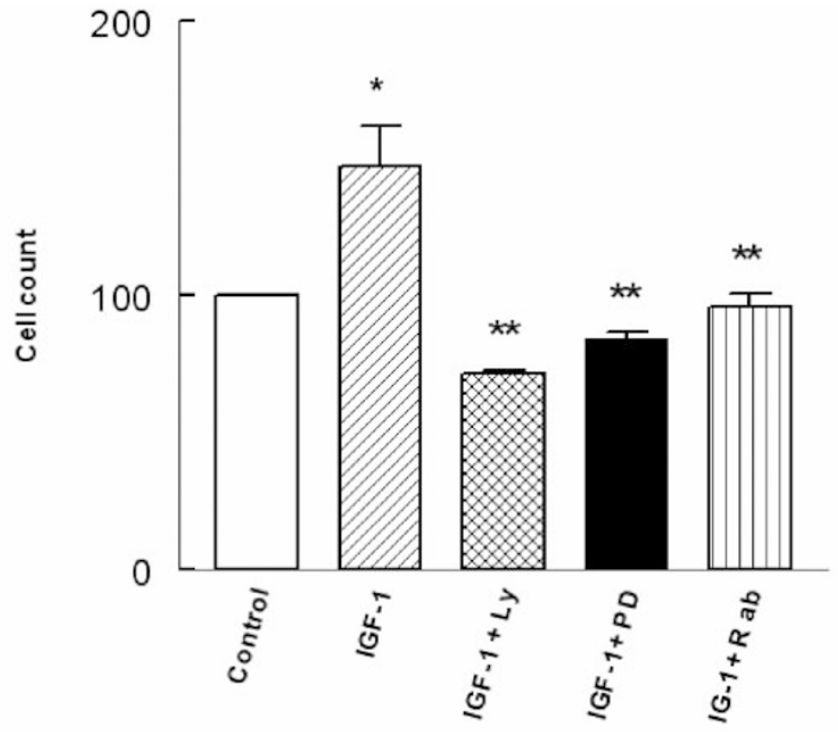

Figure 9. Cell Proliferation. MTS, a tetrazolium compound was bio-reduced into a colored formazon product by living cells in proliferation. The absorbance was measured at $490 \mathrm{~nm}$ wavelength using an Elisa plate reader. $\alpha$-sma expressing cells were scored as described in the Methods section. ${ }^{*} p<0.05$ compared with control cells; ${ }^{* *} p<0.05$ compared with cells treated with IGF-1.

increases collagen synthesis in several systems including human lung fibroblasts $(36,37)$. In these studies we found that pre-treatment with both a PI-3 kinase inhibitor reduced IGF -1 induced increases in type I collagen.

In conclusion, hyper-reactive airways in infants with bronchopulmonary dysplasia are associated with the development of smooth muscle cell hyperplasia and increased expression of collagen synthesis and $\alpha$-sma. Our present study demonstrates that these phenotypic changes in fetal lung fibroblasts may be regulated by IGF- 1 and the type I IGF- 1 receptor, and may be signaled through PI-3 kinase and activation of $\mathrm{NF}_{-} \mathrm{B}$. This provides a basis for developing strategies to interfere with IGF-1 receptor signaling to reduce or prevent the development of hyperoxia induced hyperreactive airway disease.

Acknowledgments. The study was supported by HL 67089, HL 37930, and P30 NS 047243

We thank Imclone Systems, NY, for providing us IGF-1 receptor antibody (A12), and Dr Rob Jackson, Director of the Tufts Center for Neuroscience Research for imaging support through P30 NS 047243.

\section{REFERENCES}

1. Black JL 2004 Asthma-more muscle cells or more muscular cells? Am J Respir Crit Care Med 169:980-981

2. Roche WR, Beasley R, Williams JH, Holgate ST 1989 Subepithelial fibrosis in the bronchi of asthmatics. Lancet 1:520-524

3. Zhang S, Smartt H, Holgate ST, Roche WR 1999 Growth factors secreted by bronchial epithelial cells control/ myofibroblast proliferation: an in vitro co-culture model of airway remodelling of asthma. Lab Invest 79:395-405

4. Chetty A, Manzo N, Waxman AB, Nielsen HC 2005 Modulation of IGF-binding protein-2 and -3 in hyperoxic injury in developing rat lung. Pediatr Res 58:222-228

5. Romano G 2003 The complex biology of the receptor for the insulin-like growth factor-1. Drug News Perspect 16:525-531

6. Maitre B, Clement A, Williams MC, Brody JS 1995 Expression of insulin-like growth factor receptors 1 and 2 in t/he developing lung and their relation to epithelial cell differentiation. Am J Respir Cell Mol Biol 13:262-270
7. Chetty A, Nielsen HC 2002 Regulation of cell proliferation by insulin-like growth factor-1 in hyperoxia-exposed neonatal rat lung. Mol Genet Metab 75:265-275

8. Chetty A, Faber S, Nielsen HC 1999 Epithelial-mesenchymal interaction in hyperoxic lung injury. Exp Lung Res 25:701-718

9. Izumi K, Kurosaka D, Iwata T, Oguchi Y, Tanaka Y, Mashima Y, Tsubota K 2006 Involvement of insulin-like growth /factor-I and insulin-like growth factor binding protein-3 in corneal fibroblasts during corneal wound healing. Invest Ophthalmol Vis Sci 47:591-598

10. Nixon AJ, Lillich JT, Burton-Wurster N, Lust G, Mohammed HO 1998 Differentiated cellular function in fetal chondrocytes cultured with insulin-like growth factor-I and transforming growth factor-beta. J Orthop Res 16:531-541

11. Vlahos CJ, Matter WF, Hui KY, Brown RF 1994 A specific inhibitor of phosphatidylinositol 3-kinase, 2-(4-morpholinyl)-8-phenyl-4H-1-benzopyran-4-one (LY294002). J Biol Chem 269:5241-5248

12. Dudley DT, Pang L, Decker SJ, Bridges AJ, Saltiel AR 1995 A synthetic inhibitor of the mitogen-activated p/rotein kinase cascade. Proc Natl Acad Sci USA 92:7686-7689

13. Liu W, Liu Y, Lowe JW Jr, 2001 The role of phosphatidylinositol 3-kinase and the mitogen-activated protein kinases in insulin-like growth factor-I-mediated effects in vascular endothelial cells. Endocrinology 142:1710-1719

14. Chetty A, Anderssson S, Lassus P, Nielsen HC 2004 Insulin-like growth factor-1 (IGF-1) and IGF-1 receptor (IGF-1R) expression in human lung in RDS and BPD. Pediatr Pulmonol 37:128-136

15. Chetty A, Manzo N, Waxman AB, Nielsen HC 2005 Modulation of IGF-binding protein-2 and -3 in hyperoxic injury in developing rat lung. Pediatr Res 58:222-228

16. Liu W, Liu Y, Lowe JW Jr, 2001 The role of phosphatidylinositol 3-kinase and the mitogen-activated protein kinases in insulin-like growth factor-I-mediated effects in vascular endothelial cells. Endocrinology 142:1710-1719

17. Schubert SY, Neeman I, Resnick N 20022002 A novel mechanism for the inhibition of NF-kappaB activation in vascular endothelial cells by natural antioxidants. FASEB J 16:1931-1933

18. Chetty A, Manzo N, Waxman AB, Nielsen HC 2005 Modulation of IGF-binding protein-2 and -3 in hyperoxic injury in developing rat lung. Pediatr Res 58:222-228

19. Izumi K, Kurosaka D, Iwata T, Oguchi Y, Tanaka Y, Mashima Y, Tsubota K 2006 Involvement of insulin-like growth factor-I and insulin-like growth factor binding protein-3 in corneal fibroblasts during corneal wound healing. Invest Ophthalmol Vis Sci 47:591-598

20. Zhang S, Smartt H, Holgate ST, Roche WR 1999 Growth factors secreted by bronchial epithelial cells control myofibroblast proliferation:/ an in vitro co-culture model of airway remodeling in asth/ma. Lab Invest 79:395-405

21. Kotecha S 1996 Cytokines in chronic lung disease of prematurity. Eur J Pediatr 155:S14-S17

22. Crapo JD 1986 Morphologic changes in pulmonary oxygen toxicity. Annu Rey Physiol 48:721-731

23. Hershenson MB, Kelleher MD, Naureckas ET, Abe MK, Rubinstein VJ, Zimmermann A, Bendele AM, McNulty JA, Panettieri RA, Solway J 1994 Hyperoxia increases airway cell s-phase traversal in immature rats in vivo. Am J Respir Cell Mol Biol 11:296-303

24. Black JL 2004 Ast/hma-more muscle cells or more muscular cells? Am J Respir Crit Care Med 169:980-981

25. Liu W, Liu Y, Lowe JW Jr, 2001 The role of phosphatidylinositol 3-kinase and the mitogen-activated protein kinases in insulin-like growth factor-I-mediated effects in vascular endothelial cells. Endocrinology 142:1710-1719

26. Vlahos CJ, Matter WF, Hui KY, Brown RF 1994 A specific inhibitor of phosphatidylinositol 3-kinase, 2-(4-morpholinyl)-8-phenyl-4H-1-benzopyran-4-one (LY294002). J Biol Chem 269:5241-5248

27. Dudley DT, Pang L, Decker SJ, Bridges AJ, Saltiel AR 1995 A synthetic inhibitor of the mitogen-activated protein kinase cascade. Proc Natl Acad Sci USA 92:7686-7689

28. Heck S, Lezoualc'h F, Engert S, Behl C 1999 Insulin-like growth factor-1-mediated neuroprotection against oxidative stress is associated with activation of nuclear factor kappaB. J Biol Chem 274:9828-9835

29. Finco TS, Baldwin AS 1995 Mechanistic aspects of NF-kappaB regulation: the emerging role of phosphorylation and proteolysis. Immunity 3:263-272

30. Madrid LV, Wang CY, Guttridge DC, Schottelius AJ, Baldwin ASJr., Mayo MW 2000 Akt suppresses apoptosis by stimulating the transactivation potential of the RelA/p65 subunit of NF-kappaB. Mol Cell Biol 20:1626-1638

31. Ahamed K, Epaud R, Holzenberger M, Bonora M, Flejou JF, Puard J, Clement Henrion-Caude A, 2005 A Deficiency in type 1 insulin-like growth factor receptor in mice protects against oxygen-induced lung injury. Respir Res 6:31

32. Baserga R, Sell C, Porcu P, Rubini M 1994 The role of IGF-1receptor in the growth and transformation of mammalian cells. Cell Prolif 27:63-71

33. Fedorov IA, Wilson SJ, Davies DE, Holgate ST 2005 Epithelial stress and structural remodelling in childhood asthma. Thorax 60:389-394

34. Simpson A, Maniatis N, Jury F, Cakebread JA, Lowe LA, Holgate ST, Woodcock A, Ollier WE, Collins A, Custovic A, Holloway JW, John SL 2005 Polymorphisms in a disintegrin and metalloprotease 33 (ADAM33) predict impaired early-life lung function. Am J Respir Crit Care Med 172:55-60

35. McDevitt TC, Laflamme MA, Murry CE 2005 Proliferation of cardiomyocytes derived from human embryonic stem cells is mediated via the IGF/PI 3-kinase/Akt signaling pathway. J Mol Cell Cardiol 39:865-873

36. Goldstein RH, Fine A 1986 Fibrotic reactions in the lung: the activation of lung fibroblast. Exp Lung Res 11:245-261

37. Goldstein RH, Policks CF, Pilch PF, Smith BD, Fine A 1989 Stimulation of collagen formation by insulin and insulin-like growth factor-1 in cultures of human lung fibroblasts. Endocrinology 124:964-970 